INTERNATIONAL JOURNAL OF RESEARCHES IN BIOSCIENCES, AGRICULTURE AND TECHNOLOGY (C) VISHWASHANTI MULTIPURPOSE SOCIETY (Global Peace Multipurpose Society) R. No. MH-659/13(N) www.vmsindia.org

\title{
LONAR CRATER LAKE OF INDIA: AN ABUNDANT SOURCE OF HIGHALY ECONOMIC IMPORTANT SPIRULINA
}

\author{
H. V. Wanjari and D. S. Dabhade \\ Post Graduate and Research Department of Zoology, \\ R. A. Arts, Shri M. K. Commerece and shri s. R. Rathi Science College Washim, (M.S.) 444505 \\ hemantw152@gmail.com
}

\begin{abstract}
:
Lonar Crater is the third largest natural salt-water lake in the world situated in Buldana district of Maharashtra State, India (19058'N and 76o31'E). Lonar Lake is an inland saline crater of the only one of its kind in Asia, which depicts unique limnology and biodiversity. Due to its importance to the humans study was carried out with respect to plankton especially on Spirulina. It was observed to support luxuriant bloom of pytoplakton dominated by plantensis- a protein rich blue green alga of commercial important apart from spirulina, more algal species belonging to chlorophyceae, cyanophyceae and bacillariophyceae were also present in lonar lake water. Spirulina is well known indicator of brackish water or etrophic lake water, This Lake can be used for exploitation protein rich algal biomass. This paper discusses the abundant growth of Spirulina in the Lonar crater.
\end{abstract}

Keywords: Lonar Lake, Ecological wonder, Spirulina

\section{Introduction:}

Plankton is part of aquatic life, which is composed of tiny organisms living and drifting in the direction of water current. It acts as the main source of food for most fauna, both in lotic and lentic water ecosystems (Satyanarayan et al., 2008). The Lonar Crater bears varied micro ecosystems with unique bio-diversity within. Some initial observations in this regard indicated existence of six species of algal cells, which belonged to saline water tolerant variety. A total of four sampling station were selected for the collection of algal samples from Lonar Crater. As the Lonar Lake is unique in the world for its alkalinity and salinity of the water but its alkalinity, $\mathrm{pH}$ and salinity goes on decrease day by day; (Dabhade 2006). The presence of species of bacteria related to water borne diseases were also found higher indicating the non-potable nature of the lake water but the spring (Dhara) water is normal and potable. Occurrence of few species of algae and fungi indicate the characteristic nature of bioflora, which needs the further investigations and interpretation. The assemblage of geological and micro-ecological attributes of Lonar lake water makes it very interesting for researchers. Different physico-chemical parameters were studied and analyzed (Bhawankar et al., 2011).

The lake has been polluted due to anthropogenic activities like farming, subsequent use of pesticides, discharge of sewage, developmental activities over ejecta blanket, holy rituals, tourism, etc. (Dabhade, 2006).This has created a constant threat to the ecosystem and its remarkable biodiversity; leading to the eutrophication of this lake by (Khobragade,
http://wldb.ilec.or.jp/data/ilec/WLC13_Papers /S7/s7-7.pdf, Tandale and Dabhade, 2014). The Lonar crater has attracted the attention of world geologists for investigation of its origin and the source of salinity of lake water; it is ecological wonder (Malu et al., 2007). The Crater is surrounded by ejecta blanket due to which there is no any out let to release the water from the Lake. Recently, research on its geology on line with Barrington crater by Geological Survey of India confirmed meteorite impact responsible for its origin. Uniqueness of the Crater is its salinity and alkalinity. There are microecosystem, inhabited by a wide range of plant and animal life. The saline lake, marshy areas around it, freshwater streams, natural and manmade plantations, crop fields and the remnants of the original forest and scrub referred to above, all provide special niches for plants and animals.

In Viet Nam, first culture of spirulina was conducted in 1980s (Nguyen et al., 1980). Mass culture of spirulina was started in 1990s (Kim, 1990). Spirulina platensis powder is used as a health food tablet under the brand name "Linavina" and "Pirulamin" in Viet Nam. Another canned product named as "Lactogil" is used to enhance milk secretion in mothers showing a decrease in lactation. Good results have been obtained by treating children suffering from serious malnutrition diseases with spirulina powder at Thuanhai Hospital, Viet Nam.Spirulina is an organism with a nuclear structure but no membrane, belonging to the prokaryote group of blue-green algae known as Cyanophyceae. Classic taxonomic criteria show 
the difficulty in characterizing Spirulina species adaptability to different environments. Cellular division is not mitotic. The usual organic tissues of the protoplasm are absent, yet it is considered an alga by many authors because it contains chlorophyll, like all green plants. The chlorophyll is located in the cytoplasm itself rather than in a chloroplast, and is stored in ultramicroscopic platelets that bear the complex chlorophyll pigment and carry out primary photosynthesis.

The size of the cyanobacterium cell is between 1 and 10 microns. Its wall is classic gram-negative. The granules contained in the membranes are called "phycobilisomes" and contain an essential pigment that transports energy to the PS-II, the phytocyanin that is a protein belonging to the prosthetic group. Under the microscope, it appears as a mass of intertwined unicellular spiral filaments, or trichomes, each of variable length (typically 100-200 microns) and with a diameter close to 8-10 microns. It grows and develops quickly, by cellular division, budding or even random fragmentation, in stagnant brackish and alkaline warm waters, where it forms a bluegreen slime. Because of its intertwined filaments, it can be harvested and strained on the spot (Tomaselli, 1997).

\section{Material and Methods:}

The plankton samples were collected for a years from four selected sites which were named as SI, SII, SIII and SIV, located at East, South, West and North sides of the lake respectively. Plankton sample were collected by using the plankton net. Sample observation and its photography were carried out by using COSLAB INVERTED MICROSCOPE and its TAB. and PHASE CONTRAST MICROSCOPE.

\section{Results and Discussion}

Lonar Lake is a unique basaltic rock impact crater. The Crater has different type of flora and fauna. The Lonar Crater Lake water is highly saline as well as alkaline than also there is dense amount of phytoplankton and zooplanktons are present (Dabhade et al., 2006). Lonar crater has much more forms of algal as well planktonic communities these are given below.

\section{Planktonic Diversity of Lonar Crater}

Blue green algae and bacteria were the most striking features observed in the sample. In to the high alkaline medium there is no any chance for the survival of such microscopic because of its extremely high morphological organisms than also these types of microscopic forms are extremely adapted to this condition. Luxuriant growth of Spirulina is not known anywhere except Lonar lake. Other than Spirulina, Chlorophyceae (Green algae): Chlamydomonas sp.,Oedogonium sp., Rhizoclonium sp. Cyanophyceae (Blue green algae): Anabaena sp., Arthospira, Nostoc spharicum, Ocillotoria, Spirulina subsalsa, Hydrodycton.sp. Bacillariophyceae (Diatoms): Asterionella,Closterium sp., Fragillaria, Cyclotella, Navicula, Navicula sp., Nitzschia, Nitzschia $s p$. Thus, the blue green algae constitute the major among phytoplankton community and particularly Spirulina is the dominant. The abundance of rapid multiplication of these alga are conspicuous along with other blue green algae, the Arthospira, Ocillotoria, immediately after the onset of monsoon and gradually decrease as the dry spell continues until June was reported by (Badwe et al., 1993.)

It appears that the Lonar Lake water gets slightly diluted at $\mathrm{S} 1$ and $\mathrm{S} 4$ because of the discharge of small stream in to Lonar Lake near these stations. The dilution of lake water at these sampling points makes the water quality tolerable for the growth of algae. Therefore the algal density might have been more at Station $\mathrm{S} 1$ and $\mathrm{S} 4$ while at other stations the higher levels of salts in lake water might have been responsible for relatively low count of chlorophyceae and bacillariophyceae. The algal species of cyanophyceae group were found to dominate the phytoplankton population in Lonar Lake. Bacillario-phyceae species viz. Fragillaria, Navicula and Cyclotella were found to be more tolerant to saline-alkaline lake water than chlorophyceae (green algae). The most sensitive group in Lonar Lake water was chlorophyceae. The members of chlorophyceae were found to be present only at Station 1 in very negligible amount.

Diatom species are very tolerant of widely ecological conditions. Certain species withstand definite concentrations of dissolved substances such as chlorides. The species and their relative abundance have been very useful in indicating the type of water in which the diatoms flora lives.They are used to indicate degree of pollution in the water bodies, and other variations in ecological conditions (Edmondson, 1959). 


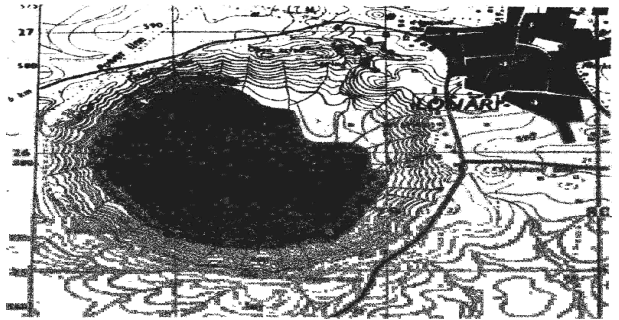

Figure. 1 Topographical Map of Lonar Crater (19058'N and 76.31'E

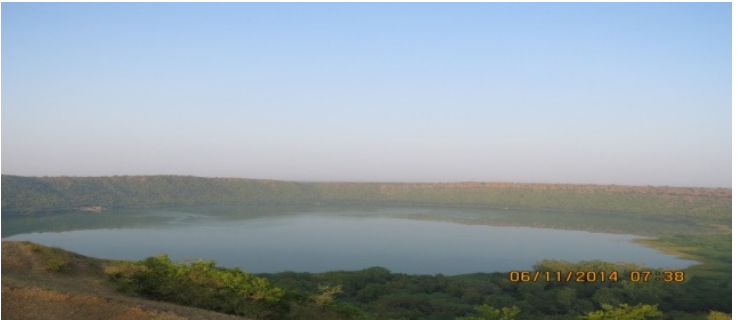

Figure. 2 View of Lonar Crater

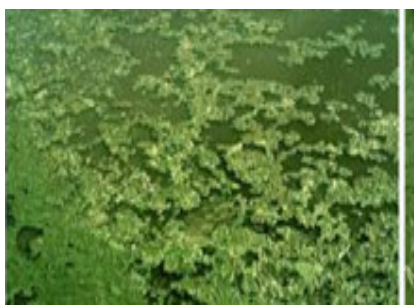

Figure. 3 Bloom of Spirulina with biomass at the Edge of Lake

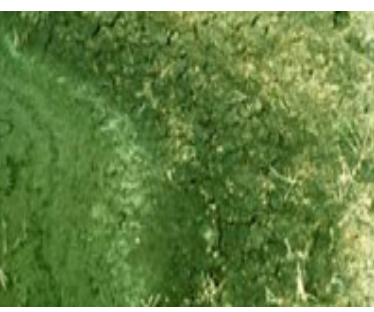

Figure. 4 Site of Spirulina Biomass.

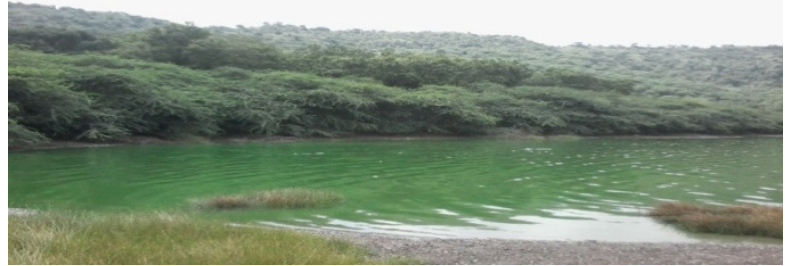

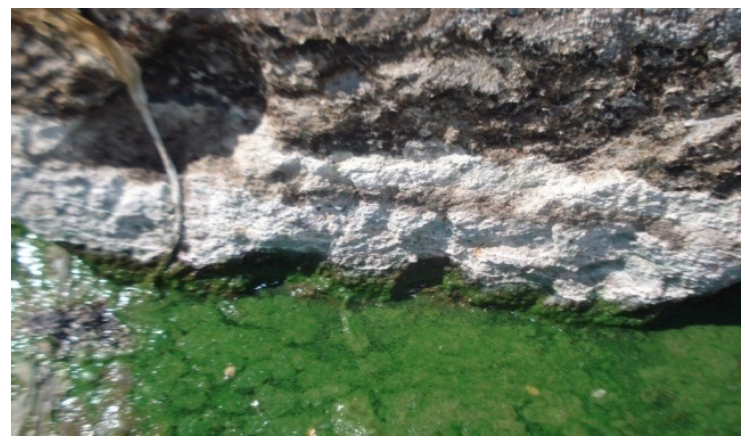

Figure.5: Development of Spirulina and salt on rock
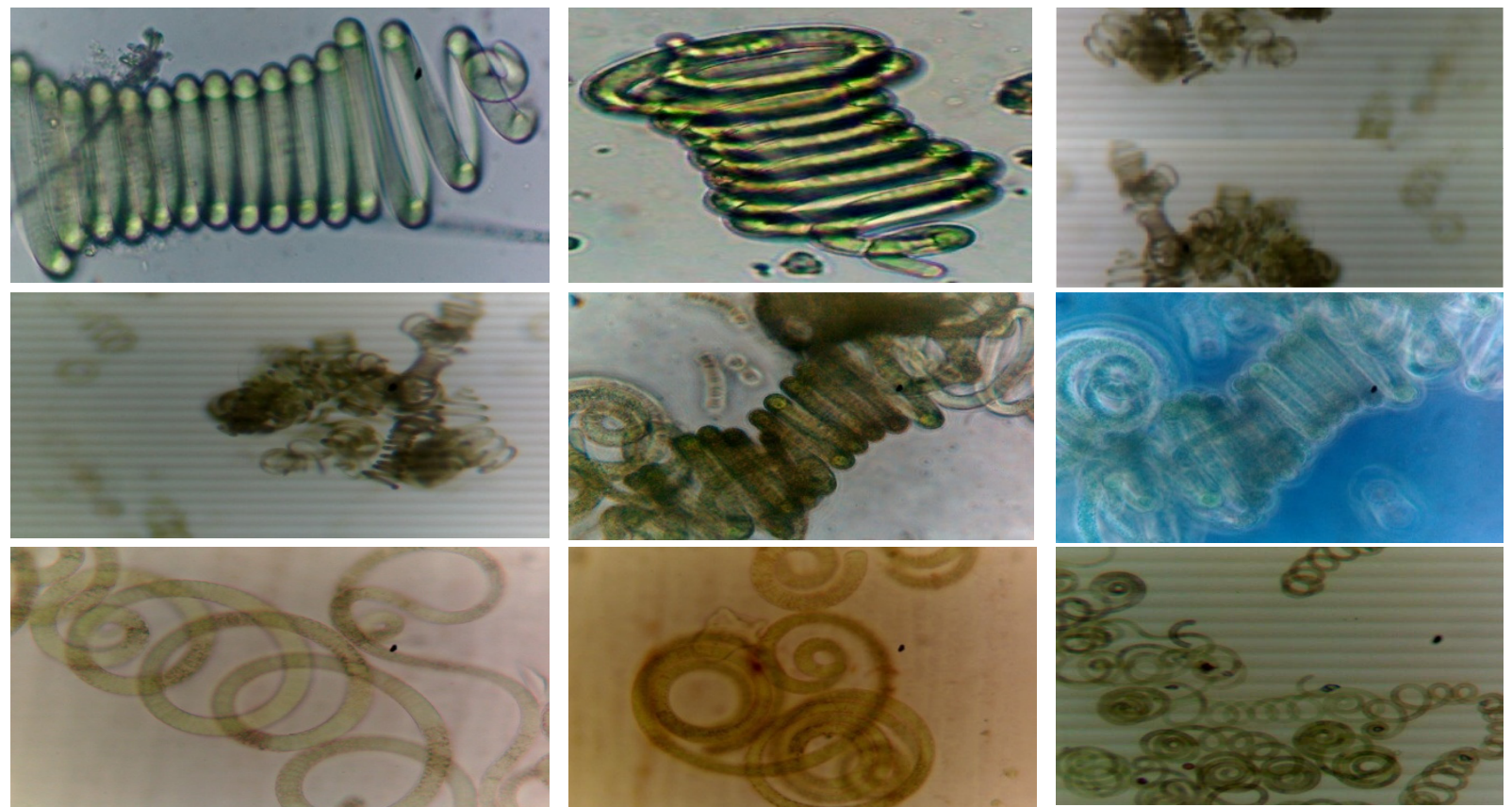

Figure. 6 Different view of Spirulina from COSLAB INVERTED MICROSCOPE and PHASE CONTRAST MICROSCOPE

\section{Chemical Composition}


Spirulina is very high in protein, very low in calories and cholesterol, and high in enzymes, minerals (iron, calcium, sodium and magnesium), and phenolic acids, which have antioxidant properties. (Phang et al., 2000, Brian and Whitton, 2012). A special value of spirulina it is readily digested due to the absence of cellulose in its cell wall (as it is case for eukaryotic green micro algae such as Chlorella, Ankistrodemus, Selenastrum, Scendesmus) after 18 hrs. More than $85 \%$ of its protein is digested and assimilated (Sasson, 1997). The essential lipids (unsaturated fatty acids) in spirulina are about $1.3-15$ percent of total lipid (6-6.5percent), mainly constituting $\gamma$ linolenic acid (30-35 percent of total lipid) (Borowitzka, 1994; Li and Qi, 1997). All the essential minerals are available in spirulina which contributes about 7 percent (average range 2.76-3.00 percent of total weight) under laboratory conditions. But in commercial spirulina production, minerals contribute about 7 percent. It bioaccumulates minerals when grown in different media, at different temperatures, $\mathrm{pH}$, salinity, etc. (Sharma and Azeez, 1988) conducted an experiment on the bioaccumulation of copper and cobalt by spirulina at different temperatures which showed a high accumulation capacity.

\section{Human Consumption}

Spirulina is rich in high quality protein, vitamins, minerals and many biologically active substances (Becker, 1994).The benefits of Spirulina as a low-calorie, high-protein, mineral and vitamin food supplement are now well established and recognized worldwide. Studies have shown that spirulina can lower cholesterol levels, stimulate the immune system and be effective in the treatment of obesity, heart disease, premenstrual stress, arthritis, anaemia and osteoporosis. (Henrikson, 1989). Phycocyanin of Spirulina platensis inhibits the growth of human leukemia K562 cells when supplemented with diet (Liu et al., 2000). Spirulina is also a rich source of betacarotene, a natural antioxidant, which the body converts to vitamin A and which plays a protective role in the human organism. Recent studies have concluded that a diet rich in vitamin $\mathrm{A}$ and provitamin A can lower the risk of cancer. Betacarotene is considered a more effective antioxidant than synthetic Tran's betacarotene. Positive results have also been seen in performance and stamina levels when Spirulina is taken as a sports supplement; the blue-green alga has a high level of biotin, which is an inhibitor of lactic acid in muscles. (Brian and
Whitton, 2012)While finally no micro-organis $\mathrm{m}$ fulfilled its promise of cheap protein, spirulina continued to give rise to research and increasing production, reflecting its perceived nutritional assets (Falquet, 2000).

\section{Extracts}

As well as being marketed in the form of tablets or capsules, Spirulina is used as an additive in pasta, drinks, cakes and a number of dietary products. (Vonshak, 1990). Spirulina produces phytocyanin, a naturally bluecoloured protein complex used as food colouring in pastry, ice creams and drinks. It is also used as a fluorescent marker in immunology. Tests in Belgium (Laboratoire de photobiologie and Laboratoire de biotechnologie algale) have demonstrated that Spirulina has healing, antiseptic and antibiotic properties, as well as the power to enhance cell regeneration. Spirulina extracts are used in a range of cosmetics, skin creams, anti-acne treatments, dermatological shampoos, skin cleansers and make-up removers. A special cream is produced for veterinary medicine to heal wounds in horses (Brian and Whitton, 2012).

\section{Animal feed}

Spirulina is used to feed ornamental carp and, in aquaculture, shrimps, mussels, trout and salmon. It enhances the colour of egg yolks and chicken meat, and is also widely used as a food additive for birds to brighten the colour of their feathers. It is fed to horses and cattle in order to foster growth and muscle tone and to improve the condition of pregnant females. (Brian and Whitton, 2012)

Table No. 1 Chemical composition of Spirulina for $10 \mathrm{~g}$ dry weight.

\begin{tabular}{|l|l|}
\hline Content & Amount \\
\hline Proteins & $6.5 \mathrm{~g}$ \\
\hline Betacarotene & $14 \mathrm{mg}$ \\
\hline Vitamin C & $2 \mathrm{mg}$ \\
\hline Thiamin (B1) & $0.37 \mathrm{mg}$ \\
\hline Riboflavin (B2) & $0.46 \mathrm{mg}$ \\
\hline Niacin & $1.3 \mathrm{mg}$ \\
\hline Calcium & $150 \mathrm{mg}$ \\
\hline Iron & $18 \mathrm{mg}$ \\
\hline Vitamin E & $0.4 \mathrm{mg}$ \\
\hline Vitamin B6 & $0.07 \mathrm{mg}$ \\
\hline Vitamin B12 & $0.02 \mathrm{mg}$ \\
\hline Phosphorus & $67 \mathrm{mg}$ \\
\hline Magnesium & $32 \mathrm{mg}$ \\
\hline Copper & $0.1 \mathrm{mg}$ \\
\hline Phycocyanin & $1500 \mathrm{mg}$ \\
\hline Gamma-linolic acid & $100 \mathrm{mg}$ \\
\hline Chlorophyll & $110 \mathrm{mg}$. \\
\hline
\end{tabular}


Fishmeal, groundnut meal and soybean meal can be partially replaced by spirulina in the preparation of diets of fish, poultry, cattle and domestic animals (Venkataraman, Somasekaran and Becker, 1994; El- Sayed, 1994 and Britz, 1996).

\section{Conclusion and Recommendation:}

Lonar Crater Lake is a wet land of important biodiversity especially for highly proteinous alga Spirulina. The hydrological study reveals deteriorating changes leading towards Eutrophication cause reduction of flora, fauna and macrophytes and increase in pathogenic organisms. It is necessary to compile the available data together, so that the remedy for the conservation of the Crater will be possible only through comprehensive conservative measures which will be conceived. Spirulina have high content of proteins, vitamins and minerals, and its high digestibility, it is use full for as an important source of food for childrens and adults of these region, where malnutrition is common. As such, Vidharbha region especially in Melghat, Gadhchiroli offers considerable potential in terms of food security for local communities. It also holds out hope as a source of income, especially for local people. At present, production levels in the Lonar Crater is nothing. Training to the local people to access the information about new idea in forms of packaging and local uses, including the feeding of animals and fish is necessary. Spirulina, common blue green algae naturally occurs in the Lonar water. The lake water can be used for mass culture of Spirulina as a bio-industry. The lake brine: supports typical microbial flora and fauna need to be investigated to access its value of wet-land to be recognized as Ramsar Site of India.

\section{References}

Badwe R. M., K. P. N. Kumaran and $L$. Rajshekher (1993): Eutrophication of Lonar lake, Maharashtra. Current Science, Vol. 65, No. 4.25 .

Becker, E.w. (1994): Microalgae. In: Nutrition. pp. 196-249. Cambridge, Cambridge University Press.

Bhawankar, A. S., L. M. Mudkhede and S. V. Shivanikar (2011): Physico-Chemical Status of Kudala Dam Tq. Umari Dist. Nanded, Maharashatra, India. J. Aqua. Biol., 26 (1): 26 30.

Borowitzka, M. A. (1994): Products from algae. In S.M. Phang, L.Y. Kun, M.A. Borowitzka \& B.A. Whitton, eds. In Proc. 1st Asia-Pacific
Conference on Algal Biotechnology. Kuala Lumpur, Malaysia. University of Malaya.

Brian A. and Whitton (2012): $8^{\text {th }}$ International Conference of algology - algae and Human affairs $21^{\text {st }}$ Century Montecatins Terme p.280282 Sodelac 2000.

Britz, P. J. (1996): The suitability of selected protein sources for inclusion in formulated diets for the South African abalone, Haliotis midae. Aquaculture, 140: 63-73.

Dabhade, D. S. (2006): Limnological studies on Lonar Crater Lake, Maharashtra. Ph.D. Thesis submitted to S.G.B. Amravati University, Amravati.

Dabhade, D. S., Malu R. A., P.S. Patil. and H. V. Wanjari (2006): Lonar Crater Lake A Wetland of Prospective Ramser Site, J. Aqua. Biol. Vol.21 (3), 14-19.

E1-Sayed, A.F.M. (1994): Evaluation of soybean meal, spirulina meal and chicken offal meal as protein sources for silver seabream (Rhabdosargus sarba) fingerlings. Aquaculture, 127: 169-176.

Falquet, J. (2000): A sustainable response to malnutrition in hot regions: the local production of spirulina, Geneva, Antenna Technologies, 2000, www.antenna.ch

Henrikson, R. (1989): Earth food Spirulina. San Rafael, California, USA, Ronorc Enterprises, Inc.

Kim, D.D. (1990): Outdoor mass culture of Spirulina platensis in Vietnam. J. Appl. Phycol., 2: 179-181.

Khobragade, K.: Limnological status of Lonar Lake with reference to Eutrophication. (http://wldb.ilec.or.jp/data/ilec/WLC13_Pap ers/S7/s7-7.pdf)

Li, D.M. and Qi, Y.Z. (1997): Spirulina Industry in China: Present status and future prospects. J. Appl. Phycol., 9: 25-28.

Liu, Y.F., L.Z. Xu, N. Cheng, L.J. Lin and C.W. Zhang (2000): Inhibitory effect of phycocyanin from Spirulina platensis on the growth of human leukemia K562 cells. J. Appl. Phycol., 12: 125-130.

Malu, R. A., D. S. Dabhade and M. S. Kodarkar (2007): Conservation and Management of Lonar Lake, An Ecological Wonder, Maharashtra, India. World Lake VisionAction report, International Lake Environment Committee Foundation (ILEC), Japan, pp 208216.

Nguyen, H.T., T.C. Nguyen, D.K. Dang and H.P.H. Dang (1980): The first results of 
investigations and cultivation of Spirulina platensis in Vietman. Rev. Hydrobiol. Bulg. Acad. Sci., 9.

Phang, S.M., M.S. Miah, w.L. Chu and M. Hashim (2000): Spirulina culture in digested sago starch factory waste water. J. Appl. Phycol., 12: 395-400.

Sasson, A. (1997): Micro Biotechnologies: Recent Developments and Prospects for Developing Countries. BIOTEC Publication 1/2542. pp. 1131. Place de Fontenoy, Paris. France. United Nations Educational,Scientific and Cultural Organization (UNESCO).

Satyanarayan, S., P.R. Chaudhari and S. Dhadse (2008): Limnological Study on Lonar Lake: A Unique Brackish Crater Lake in India Sengupta, M. and Dalwani, R. (Editors). Proceedings of Taal 2007: The 12th World Lake Conference: 2061-2066.

Sharma, R.M. and P.A. Azeez (1988): Accumulation of copper and cobalt by blue- green algae at different temperature. Inter. J. Environ. Anal. Chem., 32: 87-95.

Tandale M. R. and D. S. Dabhade (2014): The physico-chemical parameter status of Lonar Crater Lake, India, Ecological Communication Biosci. Biotech. Res. Comm. 7(1): 50-56 (2014)

Tomaselli, L. (1997): Morphology, ultrastructure and taxonomy of Arthrospira (Spirulina) maxima and Arthospira (Spirulina) platensis. In Vonshak, A., ed. Spirulina platensis (Arthrospira): Physiology, cellbiology and biotechnology. pp. 1 - 16. London, Taylor and Francis.

Venkataraman, L.V., T. Somasekaran, and E. W. Becker (1994): Replacement value of bluegreen alga (Spirulina platensis) for fish meal and a vitamin-mineral premix for broiler chicks. British Poultry Sci., 3: 373-381.

Vonshak, A. (1990): Recent advances in microalgal biotechnology. Biotech. Adv., 8: 709727. 